Société d'histoire de la révolution de 1848 et des

révolutions du XIXe siècle

$9 \mid 1993$

Utopies au XIXe siècle

\title{
La Révolution française dans la pensée politique de la "grande émigration" polonaise (1831-1870)
}

\section{Slawomir Kalembka}

\section{OpenEdition Journals}

Electronic version

URL: http://journals.openedition.org/rh19/70

DOI: $10.4000 /$ rh 19.70

ISSN: $1777-5329$

\section{Publisher}

La Société de 1848

\section{Printed version}

Date of publication: 1 June 1993

ISSN: 1265-1354

\section{Electronic reference}

Slawomir Kalembka, «La Révolution française dans la pensée politique de la "grande émigration" polonaise (1831-1870) ", Revue d'histoire du XIXe siècle [Online], 9 | 1993, Online since 09 September 2008, connection on 01 May 2019. URL : http://journals.openedition.org/rh19/70 ; DOI : 10.4000/ rh19.70

This text was automatically generated on 1 May 2019.

Tous droits réservés 
La Révolution française dans la pensée politique de la "grande émigration" polonaise (1831-1870)

Slawomir Kalembka

\section{ABSTRACTS}

No abstract available by now

Pas de résumé disponible actuellement

INDEX

Mots-clés: Révolution française, Pologne 